\title{
Association of uromodulin with acute kidney injury in patients undergoing cardiac surgery
}

\author{
Dariusz Chojęta ${ }^{1}$, Małgorzata M. Kozioł², Sylwia Targońska ${ }^{3}$, Iwona Smarz-Widelska ${ }^{4}$ \\ ${ }^{1}$ Students Scientific Association at the Chair and Department of Medical Microbiology, Medical University \\ of Lublin, Lublin, Poland \\ ${ }^{2}$ Chair and Department of Medical Microbiology, Medical University of Lublin, Lublin, Poland \\ ${ }^{3}$ Department of Cardiac Surgery, Medical University of Lublin, Lublin, Poland \\ ${ }^{4}$ Department of Nephrology, Cardinal Stefan Wyszynski Provincial Hospital, Lublin, Poland
}

Kardiochir Torakochir Pol 2020; 17 (3): 160-164

\begin{abstract}
Uromodulin (Umod) is a protein produced exclusively in the kidneys, and it is the most abundant protein in human urine. Scientific studies show that it can be a valuable diagnostic tool in monitoring kidney function. Clinical applications of Umod are probably wider. One of them is the role of a biomarker in cardiac surgery-associated acute kidney injury (CSA-AKI). Data from scientific studies indicate that a lower level of Umod in urine prior to surgery is associated with a higher risk of developing CSA-AKI after the procedure. A higher serum Umod level is suspected to be a good prognostic factor in the context of renal healing. It seems that the current state of knowledge supports the protective role of Umod in the course of AKI. Large, multi-center clinical trials would allow for the consolidation of preliminary scientific data and a more accurate understanding of the role of Umod as a CSA-AKI biomarker.
\end{abstract}

Key words: uromodulin, Tamm-Horsfall protein, cardiac surgeryassociated acute kidney injury, kidney disease.

\section{Introduction}

Uromodulin (Umod), also called the Tamm-Horsfall protein (THP), is a long-known glycoprotein that is the most abundant physiological urine protein. It is produced exclusively within the kidneys, mainly by the epithelial cells of the thick ascending limb of the loop of Henle (TAL). A significant amount is secreted by the apical membrane of cells into the lumen of the renal tubules. Due to basolateral secretion, the protein from the renal interstitium enters the bloodstream in a small amount [1-3]. Many physiological functions have been attributed to Umod, including participation in the prevention of urinary tract infections and maintenance of water

\section{Streszczenie}

Uromodulina (Umod) jest białkiem produkowanym wyłącznie w nerkach, a wydzielana do moczu stanowi w nim najobfitsze białko. Badania naukowe dowodzą, że może stanowić wartościowe narzędzie diagnostyczne w monitorowaniu funkcji nerek. Korelacje i wynikające z nich kliniczne zastosowania Umod mogą być prawdopodobnie szersze. Jednym z nich jest rola biomarkera w ostrym uszkodzeniu nerek związanym z operacjami kardiochirurgicznymi (CSA-AKI). Dane pochodzące z badań naukowych wskazują, że niższe stężenie Umod w moczu przed operacją wiąże się z większym ryzykiem rozwoju CSA-AKI. Przypuszcza się także, że wyższe stężenie Umod w surowicy u pacjentów z rozpoznanym powikłaniem jest dobrym czynnikiem rokowniczym w procesie zdrowienia nerek. Wydaje się, że obecny stan wiedzy potwierdza pogląd ochronnej roli tego białka w przebiegu AKI. Potrzebne są duże, wieloośrodkowe badania kliniczne, których wyniki pozwolityby na konsolidację wstępnych danych naukowych oraz na dokładniejsze poznanie i opisanie roli Umod jako biomarkera CSA-AKI.

Słowa kluczowe: uromodulina, białko Tamma-Horsfalla, ostre uszkodzenie nerek związane z operacjami kardiochirurgicznymi, choroby nerek.

and electrolyte homeostasis [4-6]. Currently, on the diagnostic market, there are tests enabling quantitative determination of this parameter in urine (urinary uromodulin - uUmod) or in the blood (serum uromodulin - sUmod) using immunoenzymatic techniques [7]. Recent scientific studies support the huge potential of using uromodulin as a biomarker of renal function. The positive association of estimated glomerular filtration rate (eGFR) values with sUmod and uUmod levels has been described, although in this application the correlation of sUmod seems to be stronger [8]. Despite the fact that clinical use in particular types of kidney dysfunction still requires further and more accurate development, the

Address for correspondence: Dariusz Chojęta, Students Scientific Association at the Chair and Department of Medical Microbiology, Medical University of Lublin, Lublin, Poland, e-mail: dariusz.chojeta@gmail.com

Received: 8.06.2020, accepted: 28.08.2020. 
current state of knowledge shows THP to be a very valuable tool that could complement traditional renal parameters. Associations between protein concentration and individual metabolic syndrome parameters were also described, as well as the use in estimating the risk of mortality among patients with cardiovascular diseases $[9,10]$.

Patients with cardiovascular diseases sometimes require surgical intervention, most often due to developed and advanced coronary artery disease (CAD). People undergoing cardiac surgery are a special group of patients burdened with many risk factors for postoperative complications. One of them is acute kidney injury (AKI), defined as a clinical syndrome characterized by the sudden development of renal impairment. Early diagnosis allows the implementation of an appropriate therapeutic process [11]. For this reason, a parameter whose value changes before the development of AKI is intensively sought. It is possible that such a biomarker would allow the selection of patients at the highest degree of risk after surgery, to whom special attention should be paid and who should be monitored more frequently. The association of uromodulin with AKI appears to have a complex pathophysiological background, as yet not fully understood. Nevertheless, scientific studies are increasingly emphasizing the role of this parameter as a predictor of AKI in patients after cardiac surgery. The objective of this review is to analyze available evidence of uromodulin as a biomarker of AKI in cardiac surgery patients. The work was based on the PubMed and Google Scholar databases, mainly on articles published in the last 5 years.

\section{Recognition of acute kidney injury}

According to the definition of KDIGO 2012 (Kidney Disease Improving Global Outcomes), the diagnosis of AKI can be made if at least one of the following criteria is present [11]: - Increase in serum creatinine by $\geq 0.3 \mathrm{mg} / \mathrm{dl}(26.5 \mu \mathrm{mol} / \mathrm{l})$ within 48 hours;

- Increase in serum creatinine by $\geq 1.5$ times the initial value, confirmed or suspected to have occurred in the last 7 days;

- Urine volume $<0.5 \mathrm{ml} / \mathrm{kg} / \mathrm{h}$ for 6 hours.

The same guidelines developed a 3-step scale of AKI severity based on an increase in serum creatinine and/or a decrease in diuresis [11]. It is recommended to actively search for the root cause of AKI in every patient. For the purpose of risk assessment, possible exposure and vulnerability states for the occurrence of a non-specific AKI incident have been described. Among them, cardiac surgery especially with the use of cardiopulmonary bypass (CPB), or the use of radiocontrast agents during procedures such as coronarography, were mentioned. In addition, among patient-dependent factors, the presence of chronic kidney disease (CKD) is indicated as a state of increased susceptibility [11]. The spectrum of symptoms and their severity in the course of AKI is relatively broad, depending on the primary cause or clinical condition of the patient. Laboratory abnormalities may be the only impairment that is transient and resolves without complications. However, in some patients, the recovery process may be unsuccessful and AKI may become the starting point for the development of CKD [12].

\section{Cardiac surgery-associated acute kidney injury}

Many different procedures are performed in cardiac surgery departments. Among them, the most common are methods of surgical treatment of advanced CAD, mainly coronary artery bypass grafting (CABG) in extracorporeal circulation. Each operation is fraught with the possibility of complications, including infectious and blood loss related complications. One of the challenges in medical practice is cardiac surgery-associated acute kidney injury (CSAAKI). It is estimated that this complication affects about $30 \%$ of adults [13] and about $50 \%$ of pediatric patients [14]. CSA-AKI (even in its mild form) is independently associated with increased perioperative mortality, adverse overall short- and long-term prognosis, prolonged hospitalization, higher costs of care, and an increased risk of developing CKD and hypertension [15-18]. About $1-5 \%$ of patients may require renal replacement therapy, which significantly worsens the prognosis [19]. The pathophysiology of CSA$A K I$ is currently not fully explained. It is considered to be very complex and multifactorial, and the impact of individual variables can be different for each patient (Table I) $[19,20]$. On this basis, recommendations to avoid the use of nephrotoxic drugs, the shortest possible use of extracorporeal circulation techniques and control of hemodynamic equalization in patients undergoing heart surgery seem justified [20].

Despite the multitude and complexity of risk factors (Table II), difficulties in eliminating them all and the lack of effective prevention of the disorder, it seems reasonable to identify patients with an increased likelihood of developing CSA-AKI. There is no specific prophylaxis, but after selecting patients at increased risk of this complication, frequent monitoring of cardiac and kidney function would be

Table I. Pathophysiology of CSA-AKI [19, 20]

\begin{tabular}{ll} 
No. & Pathophysiology \\
\hline 2 & Genetic factors - individual variation \\
\hline 3 & The effect of exogenous toxins - the use of nephrotoxic, \\
radiocontrast agents or nephrotoxic drugs \\
The phenomenon of vasoconstriction and kidney \\
hypoperfusion - leads to a decrease in glomerular filtration \\
- Hemodynamic imbalance - low blood pressure, low \\
cardiac output \\
- The use of CPB (and other forms of extracorporeal \\
circulation) - increased risk of hemolysis, and thus \\
the production of free radicals and damage caused by \\
hemoglobin released into the blood \\
- Development of the systemic process of oxidative stress \\
and inflammation \\
- Neurohormonal factors (sympathetic activation, activation \\
of the renin-angiotensin-aldosterone system)
\end{tabular}


Table II. Risk factors of CSA-AKI $[11,14,19]$

\begin{tabular}{ll} 
Category & Risk factors \\
$\begin{array}{ll}\text { Patient-related } \\
\text { factors }\end{array}$ & - Female gender \\
& - Advanced age (pediatric patients - age \\
& under 2 years) \\
& - Chronic diseases: chronic kidney disease \\
& (CKD), chronic obstructive pulmonary disease \\
& (COPD), diabetes, heart failure, live failure \\
& - History of previous surgery (including cardiac \\
& surgery) \\
\hline Surgery-related & - Type of surgery \\
factors & - CPB duration over 100-120 minutes \\
& - Use of contrast agents and/or nephrotoxic \\
& drugs \\
\hline Postoperative & - States of lown time \\
factors & - Hypovolemia, low blood pressure \\
& - Sepsis \\
& - Atheroembolism \\
& Use of nephrotoxic drugs \\
\hline
\end{tabular}

desirable, which would translate into the earlier diagnosis of AKI and faster use of available forms of treatment [19]. This prompted scientists to actively search for biomarkers of renal tubular function in the perioperative period, which could identify patients from high-risk groups [21].

\section{Uromodulin level in cardiac patients}

In the search for an AKI predictor, the researchers' attention focused on, among others, neutrophil gelatinase-associated lipocalin (NGAL) determinations in urine and blood plasma in the early postoperative phase $[22,23]$. There are probably more substances with similar applications - interleukin-18 (IL-18) in urine or kidney injury molecule-1 (KIM-1) glycoprotein in the blood seems to show a potential connection with the prediction and early diagnosis of AKI [24, 25]. The use of biomarkers that predict the occurrence of CSA-AKI in the preoperative period seems to be extremely important. Uromodulin, also called Tamm-Horsfall protein, seems to fulfill this criterion.

Studies by El-Achkar et al. on the role of uromodulin in the in vivo-induced ischemia-reperfusion mechanism (IRI) of the kidneys in a mouse model have become the basis of interest in this glycoprotein in the context of risk stratification of AKI development after cardiac surgery. In their experiments, the researchers found that Umod knockout (Umod -/-) mice had higher peak serum creatinine [26] and a greater range of histological damage in the S3 segment of proximal tubules [27], compared to wild type mice. Molecular studies have also shown that Umod expression increases within 48 hours after IRI and that there is a redirection of protein from TAL cells towards the basolateral membrane and renal interstitium. This redistribution of uromodulin may translate into an increase in its serum concentration, which could probably be used as a prognostic marker for assessing recovery in AKI [28]. Therefore, it seems very likely that in states of acute injury of the kidneys, uromodulin has a protective effect - it strongly suppresses inflammation in the renal interstitium, reduces the extent of damage of the renal tubules and accelerates the healing process [28, 29].

Previous studies have assessed the role of preoperative uUmod level value in determining the risk of developing CSAAKI in the postoperative period. One of them, performed by Garimella et al., included a large group of 218 adults undergoing on-pump cardiac surgery [30]. AKI was diagnosed in $29 \%$ of patients, although the diagnosis was extended to 72 hours (relative to 48 hours recommended by the KDIGO) due to the expected postoperative decrease in serum creatinine due to pre-operative hemodilution. The uromodulin to creatinine ratio was determined in pre-operative urine samples and had a median of $10 \mu \mathrm{g} / \mathrm{g}$. Considering the multidimensional profile of risk factors, the analysis showed that a lower urinary uUmod to creatinine ratio was associated with a higher risk of developing AKI. Each lower standard deviation was associated with a higher corrected peak blood creatinine concentration during 72-hour postoperative follow-up $(0.07 \mathrm{mg} / \mathrm{dl}$ on SD; $95 \%$ confidence interval, 0.02 to 0.13 ) [30].

In the pediatric patient population, the incidence of AKI after cardiac surgery appears to be higher. Bennett et al. in a group of children undergoing CPB surgery, diagnosed AKI in up to $47 \%$ [14]. Umod determinations were carried out in the urine, and the lowest measured pre-operative protein quartile had about 132 times greater risk of developing a complication compared to the highest quartile. The average uUmod levels were significantly higher in children without AKI compared to those in whom this complication developed $(13.7 \mu \mathrm{g} / \mathrm{ml}$ vs. $4.739 \mu \mathrm{g} / \mathrm{ml})$. Based on the results of the study, the protective role of uromodulin and the potential use of its preoperative concentration as a predictor of CSA-AKI can be confirmed.

The association of uromodulin with AKI appears to have a complex pathophysiological background, as yet not fully understood. It is very likely that Umod has local protective and anti-inflammatory effects on the renal tubules and the renal interstitium in acute injury states, which has been confirmed in in vivo studies using the IRI model [28, 29]. AKI is one of those clinical conditions in which transient THP deficiency develops [29, 31]. Based on scientific evidence, our current state of knowledge allows us to determine the presumed and preliminary role of Umod as an AKI biomarker, in particular in CSA-AKI (Figure 1). Scientific studies have shown a correlation between a lower uUmod level and a higher risk of development and a greater likelihood of AKI diagnosis $[14,30]$. It is also possible that the degree of THP deficiency correlates with the severity of the disorder. It seems that a higher level of sUmod can be a good prognostic factor for a successful and faster recovery process [28]. Additionally, it is pointed out that serial determination of Umod level may provide more information and allow for better understanding and monitoring of the course of the disease [31]. It is also worth noting that all the associations of THP level so far described with various stages of AKI diagnostics do not indicate specific numerical values and norm limits, but only the ratio of the Umod level quartiles relative to each other (lower/higher) in a clinical trial. 


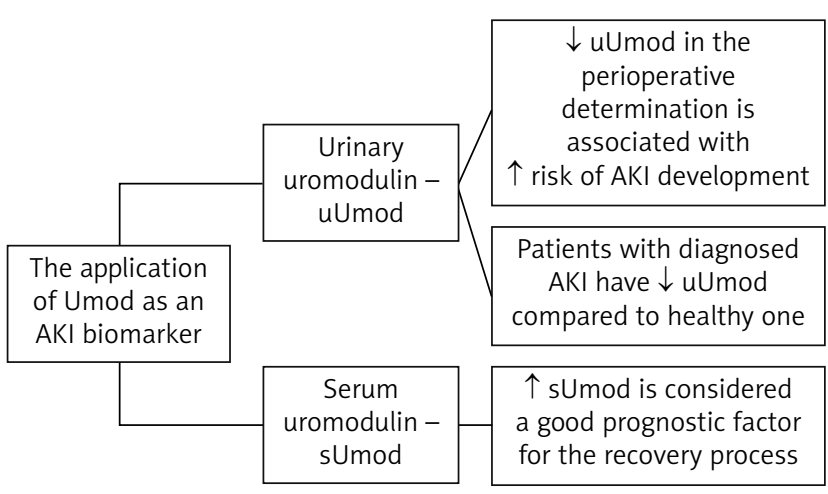

Figure 1. Application of uromodulin as an AKI biomarker (in the example of the CSA-AKI model) $[14,28,30,31]$

As mentioned before, diagnosed chronic kidney disease (CKD) is a condition of increased susceptibility to the development of a non-specific AKI incident [11]. Determination of uromodulin level can be a valuable diagnostic tool and a supplement for standard monitoring of renal function, while the correlation of sUmod level in this aspect seems stronger than for uUmod [8]. Umod concentration is also associated with the degree of metabolic control of diabetes (diabetes is a risk factor for CKD) [32]. For these reasons, we can assume that patients undergoing cardiac surgery may benefit from serial measurements of THP level. This is not related to the role of this protein as a CSA-AKI biomarker, but it is related to prophylaxis in the form of monitoring the course of kidney diseases, which can directly or indirectly increase the risk of AKI as a complication of the surgery. One more association can be found in the use of uromodulin in patients undergoing cardiac surgery. A scientific study by Delgado et al. on a large population of over 3,000 participants undergoing coronary artery angiography showed that higher levels of sumod are associated with a lower incidence of cardiovascular disease (hypertension, heart failure, diabetes) and a lower rate of 10-year mortality. On this basis, researchers speculate that uromodulin can be successfully used to predict cardiovascular risk while being a marker of kidney health [33].

\section{Conclusions}

AKI is a serious complication of cardiac surgery. It is associated with prolonged hospitalization, the risk of developing CKD in the future, and higher mortality rate. Identifying patients with risk of developing AKI is an important step to minimize this postoperative complication. The determination of urinary Umod as a renal tubular biomarker may be valuable in stratifying the hazard ratio in the preoperative period, as well as in monitoring the process of renal healing. It seems to be possible to identify patients from a high-risk group for occurrence of CSA-AKI, which could translate into attempts to minimize the impact of modifiable risk factors and initiate early treatment. In addition, sUmod levels could probably be used in prognosis in the context of the recovery process in already developed dis- orders. Large, multicenter clinical trials using both types of tests (in urine and in blood serum) performed serially in the pre- and postoperative periods would be very helpful in better understanding the role of uromodulin as a CSA-AKI biomarker.

\section{Disclosure}

The authors report no conflict of interest.

\section{References}

1. Bachmann S. A novel role for Tamm-Horsfall protein (uromodulin) in the renal tubule. Kidney Int 2018; 94: 652-655.

2. Lhotta K. Uromodulin and chronic kidney disease. Kidney Blood Pressure Res 2010; 33: 393-398.

3. Scherberich JE, Gruber R, Nockher WA, et al. Serum uromodulin - a marker of kidney function and renal parenchymal integrity. Nephrol Dialysis Transpl 2018; 33: 284-295.

4. Garimella PS, Bartz TM, Ix JH, et al. Urinary uromodulin and risk of urinary tract infections: the cardiovascular health study. Am J Kidney Dis 2017; 69: 744-751.

5. Wolf MT, Zhang J, Nie M. Uromodulin in mineral metabolism. Curr Opin Nephrol Hypertens 2019; 28: 481-489.

6. Zacchia M, Capasso G. The importance of uromodulin as regulator of salt reabsorption along the thick ascending limb. Nephrol Dialysis Transpl 2015; 30: 158-160.

7. Youhanna S, Weber J, Beaujean V, et al. Determination of uromodulin in human urine: influence of storage and processing. Nephrol Dialysis Transpl 2014; 29: 136-145.

8. Steubl D, Buzkova P, Ix JH, et al. Association of serum and urinary uromodulin and their correlates in older adults - The Cardiovascular Health Study. Nephrology 2020; 25: 522-526.

9. Then $\mathrm{C}$, Then $\mathrm{H}$, Lechner A, et al. Serum uromodulin is inversely associated with the metabolic syndrome in the KORA F4 study. Endocrine Connections 2019; 8: 1363-1371.

10. Steubl D, Buzkova P, Garimella PS, et al. Association of serum uromodulin with mortality and cardiovascular disease in the elderly - the Cardiovascular Health Study. Nephrol Dialysis Transpl 2020; 35: 1399-1405.

11. Kellum JA, Lameire N, Aspelin P, et al. Kidney disease: improving global outcomes (KDIGO) acute kidney injury work group. KDIGO clinical practice guideline for acute kidney injury. Kidney Int Suppl 2012; 2: 1-138.

12. Ferenbach DA, Bonventre JV. Mechanisms of maladaptive repair after AKI leading to accelerated kidney ageing and CKD. Nature Rev Nephrol 2015; 11: 264-276.

13. Rosner MH, Okusa MD. Acute kidney injury associated with cardiac surgery. Clin J Am Soc Nephrol 2006; 1: 19-32.

14. Bennett MR, Pyles O, Ma Q, Devarajan P. Preoperative levels of urinary uromodulin predict acute kidney injury after pediatric cardiopulmonary bypass surgery. Pediatr Nephrol 2018; 33: 521-526.

15. Mao H, Katz N, Ariyanon W, et al. Cardiac surgery-associated acute kidney injury. Cardiorenal Med 2013; 3: 178-199.

16. Ortega-Loubon C, Fernández-Molina M, Carrascal-HinojalY, Fulquet-Carreras E. Cardiac surgery-associated acute kidney injury. Ann Cardiac Anaesthesia 2016; 19: 687-698.

17. Lim CC, Tan CS, Chia CM, et al. Long-term risk of progressive chronic kidney disease in patients with severe acute kidney injury requiring dialysis after coronary artery bypass surgery. Cardiorenal Med 2015; 5: 157-163.

18. Hsu CY, Hsu RK, Yang J, et al. Elevated BP after AKI. J Am Soc Nephrol 2016; 27: 914-923.

19. Wang Y, Bellomo R. Cardiac surgery-associated acute kidney injury: risk factors, pathophysiology and treatment. Nat Rev Nephrol 2017; 13: 697-711.

20. Bellomo R, Auriemma S, Fabbri A, et al. The pathophysiology of cardiac surgery-associated acute kidney injury (CSA-AKI). Int J Artif Organs 2008; 31: 166-178.

21. Wu B, Chen J, Yang Y. Biomarkers of acute kidney injury after cardiac surgery: a narrative review. Biomed Res Int 2019; 2019: 7298635.

22. Cruz DN, Gaiao S, Maisel A, et al. Neutrophil gelatinase-associated lipocalin as a biomarker of cardiovascular disease: a systematic review. Clin Chem Labor Med 2012; 50: 1533-1545. 
23. Tidbury N, Browning N, Shaw M, et al. Neutrophil gelatinase-associated lipocalin as a marker of postoperative acute kidney injury following cardiac surgery in patients with preoperative kidney impairment. Cardiovasc Haematol Disord Drug Targets 2019; 19: 239-248.

24. Lin X, Yuan J, Zhao Y, Zha Y. Urine interleukin-18 in prediction of acute kidney injury: a systemic review and meta-analysis. J Nephrol 2015; 28: 7-16.

25. Ibrahim NE, McCarthy CP, Shrestha S, et al. Blood kidney injury molecule-1 predicts short and longer term kidney outcomes in patients undergoing diagnostic coronary and/or peripheral angiography - results from the Catheter Sampled Blood Archive in Cardiovascular Diseases (CASABLANCA) study. Am Heart J 2019; 209: 36-46.

26. El-Achkar TM, Wu XR, Rauchman M, et al. Tamm-Horsfall protein protects the kidney from ischemic injury by decreasing inflammation and altering TLR4 expression. Am J Physiol Renal Physiol 2008; 295: F534-F544.

27. El-Achkar TM, McCracken R, Rauchman M, et al. Tamm-Horsfall proteindeficient thick ascending limbs promote injury to neighboring S3 segments in an MIP-2-dependent mechanism. Am J Physiol Renal Physiol 2011; 300: F999-F1007.
28. El-Achkar TM, McCracken R, Liu Y, et al. Tamm-Horsfall protein translocates to the basolateral domain of thick ascending limbs, interstitium, and circulation during recovery from acute kidney injury. Am J Physiol Renal Physiol 2013; 304: F1066-F1075.

29. El-Achkar TM, Wu XR. Uromodulin in kidney injury: an instigator, bystander, or protector? Am J Kidney Dis 2012; 59: 452-461.

30. Garimella PS, Jaber BL, Tighiouart H, et al. Association of preoperative urinary uromodulin with AKI after cardiac surgery. Clin J Am Soc Nephrol 2017; 12: 10-18.

31. Micanovic R, LaFavers K, Garimella PS, et al. Uromodulin (Tamm-Horsfall protein): guardian of urinary and systemic homeostasis. Nephrol Dialysis Transpl 2020; 35: 33-43.

32. Leiherer A, Muendlein A, Saely $\mathrm{CH}$, et al. Serum uromodulin is associated with impaired glucose metabolism. Medicine 2017; 96: e5798.

33. Delgado GE, Kleber ME, Scharnagl $\mathrm{H}$, et al. Serum uromodulin and mortality risk in patients undergoing coronary angiography. J Am Soc Nephrol 2017; 28: 2201-2210. 